\title{
Peningkatan aktivitas fagositosis dan produksi nitrit oksida pada makrofag peritoneum tikus Sprague Dawley yang diberi Lactobacillus plantarum Mut7 dan ekstrak serat ubi jalar
}

\section{Enhancement of phagocytic activity and nitric oxide production of peritoneal macrophage of Sprague Dawley rats fed with Lactobacillus plantarum Mut7 and sweet potato fiber}

Lily Arsanti Lestari ${ }^{1}$, Marsetyawan Heparis Nur Ekandaru Soesatyo², Susi Iravati ${ }^{3}$, Eni Harmayani ${ }^{4}$

\begin{abstract}
Background: Macrophages play an important role as part of the innate immune response in the gut and they represent one of the first lines of nonspecific defense against bacterial invasion. Previous studies indicated that probiotics and prebiotics may act as an immunomodulator agents. Nevertheless, research on the immunomodulatory effect of local materials has never been performed.

Objective: To study the effects of Lactobacillus plantarum Mut7 and sweet potato fiber on the activity and Nitric Oxide (NO) production of peritoneal macrophages of Sprague Dawley rats.

Method: Ninety six Sprague Dawley rats aged 8 weeks were divided into two groups; A (not infected with Salmonella typhimurium) and B (infected with $S$. typhimurium). Each group was divided into 4 subgroups and assigned to standard AIN-93M diet (KON), $10^{9} \mathrm{CFU} / \mathrm{ml}$ of L. plantarum Mut7 (PRO), modified AIN-93M diet with sweet potato fiber (PRE), and both component (SIN). After 3 weeks of treatment, 6 rats of each subgroup were sacrificed and the peritoneal macrophages were isolated and analysed for its activity and NO production. The rest of the rats continued the treatments for another 2 weeks. At the end of the experiment, they were sacrificed and the peritoneal macrophage were isolated and analysed for its activity and NO production.

Results: Oral administration of L. plantarum Mut7, sweet potato fiber, or both improve phagocytic activity of peritoneal macrophage which was indicated by an increase in the percentage of macrophages that phagocyte latex particles $(p<0.05)$ and an increase in the number of latex particles engulfed by macrophages either after 3 or 5 weeks of treatment $(p<0.05)$. Oral administration of L. plantarum Mut7, sweet potato fiber, or both were unable to increase the nitric oxide production after 3 weeks of treatment $(p>0.05)$, but after 5 weeks of treatment the production of NO was significantly increased $(p<0.05)$.

Conclusion: L. plantarum Mut7, sweet potato fiber, or both increase the non specific immune response as they could improve the activity and NO production of peritoneal macrophages.
\end{abstract}

KEY WORDS: L. plantarum Mut7, sweet potato fiber, peritoneal macrophage, nitric oxide

\begin{abstract}
ABSTRAK
Latar belakang: Makrofag mempunyai peranan penting sebagai bagian dari respon imun alami dalam sistem imun di saluran cerna dan merupakan salah satu garis terdepan dalam pertahanan terhadap invasi bakteri. Penelitian sebelumnya menunjukkan bahwa probiotik dan prebiotik dapat berperan sebagai agensia imunomodulator. Namun, penelitian tentang efek imunomodulator dari bahan lokal belum dilakukan.

Tujuan: Tujuan penelitian ini adalah untuk mempelajari pengaruh pemberian Lactobacillus plantarum Mut7 dan serat ubi jalar pada aktivitas fagositosis dan produksi Nitrit Oksida (NO) pada makrofag peritoneum tikus Sprague Dawley. Metode: Sembilan puluh enam ekor tikus Sprague Dawley berusia 8 minggu dibagi menjadi dua kelompok yaitu kelompok A (tidak terinfeksi dengan Salmonella typhimurium) dan kelompok B (terinfeksi S. typhimurium). Setiap kelompok dibagi menjadi 4 subkelompok yang diberi perlakuan berupa diit standar AIN-93M (KON), L. plantarum Mut7 sebanyak $10^{\circ} \mathrm{CFU} /$ ml (PRO), diit AIN-93M dimodifikasi dengan serat ubi jalar (PRE), dan gabungan PRO dan PRE (SIN). Setelah 3 minggu perlakuan, 6 tikus dari setiap subkelompok dikorbankan dan makrofag peritoneum diisolasi untuk dianalisis aktivitas fagositosis dan produksi NO. Tikus yang tersisa diberi perlakuan yang sama selama 2 minggu. Pada akhir percobaan, semua tikus dikorbankan dan makrofag peritoneum diisolasi untuk dianalisis aktivitas fagositosis dan produksi NO. Hasil: Pemberian L. plantarum Mut7, serat ubi jalar, atau keduanya dapat meningkatkan aktivitas fagositosis makrofag
\end{abstract}

\footnotetext{
${ }^{1}$ Korespondensi: Program Studi Gizi Kesehatan, Fakultas Kedokteran Universitas Gadjah Mada, Jl. Farmako, Sekip Utara, Yogyakarta 55281, e-mail: santi_wap@yahoo.com

2 Bagian Histologi dan Biologi Sel, Fakultas Kedokteran Universitas Gadjah Mada, Jl. Farmako, Sekip Utara, Yogyakarta 55281

${ }^{3}$ Bagian Mikrobiologi, Fakultas Kedokteran Universitas Gadjah Mada, Jl. Farmako, Sekip Utara, Yogyakarta 55281

4 Jurusan Teknologi Pengolahan Hasil Pertanian, Fakultas Teknologi Pertanian Universitas Gadjah Mada, Jl. Flora No. 1, Bulaksumur, Yogyakarta 55281
} 
peritoneum yang ditandai dengan peningkatan persentase makrofag yang memfagosit partikel lateks $(p<0,05)$ dan peningkatan jumlah partikel lateks yang difagosit oleh makrofag baik setelah 3 atau 5 minggu perlakuan $(p<0,05)$. Pemberian L. plantarum Mut7, serat ubi jalar, atau keduanya tidak dapat meningkatkan produksi NO setelah 3 minggu perlakuan $(p>0,05)$. Namun, ketiga perlakuan tersebut dapat meningkatkan produksi NO setelah 5 minggu perlakuan $(p<0,05)$.

Simpulan: L. plantarum Mut7, serat ubi jalar, atau keduanya dapat meningkatkan respon imun non spesifik yang ditandai dengan peningkatan aktivitas fagositosis dan produksi NO oleh makrofag peritoneum.

KATA KUNCI: L. plantarum Mut7, serat ubi jalar, makrofag peritoneum, nitrit oksida

\section{PENDAHULUAN}

Menurut Badan Pengawasan Obat dan Makanan (BPOM), pangan fungsional adalah pangan olahan yang mengandung satu atau lebih komponen fungsional yang berdasarkan kajian ilmiah mempunyai fungsi fisiologis tertentu, terbukti tidak membahayakan, dan bermanfaat bagi kesehatan. Komponen pangan fungsional digolongkan menjadi 15 macam yaitu vitamin, mineral, gula alkohol, asam lemak tidak jenuh, peptida dan protein tertentu, asam amino, serat pangan, prebiotik, probiotik, kolin, lesitin dan inositol, karnitin dan skualen, isoflavon (kedelai), fitosterol dan fitostanol, polifenol (teh), serta komponen fungsional lain yang akan ditetapkan kemudian (1). Berdasarkan penjelasan dari BPOM tersebut, pemerintah Indonesia telah mencantumkan probiotik dan prebiotik dalam komponen pangan fungsional. Hal ini telah mendorong perkembangan produk-produk pangan fungsional yang mengandung kedua komponen tersebut.

Penelitian pangan fungsional yang mengandung probiotik dan prebiotik di Indonesia pada 10 tahun terakhir meningkat dengan diisolasinya bakteri probiotik dari sumber lokal dan komponen prebiotik dari umbiumbian lokal yang berasal dari Indonesia. Lactobacillus plantarum Mut7 merupakan bakteri asam laktat yang diisolasi dari air rendaman gatot dan telah diuji potensinya sebagai probiotik. Ubi jalar varietas Bestak merupakan ubi jalar lokal yang telah diketahui mengandung beberapa komponen prebiotik seperti frukto oligo sakarida (FOS), inulin, dan rafinosa (2).

Bakteri probiotik dan komponen prebiotik diketahui dapat meningkatkan respon imun baik respon imun alami maupun adaptif. Probiotik berinteraksi dengan sistem imun mukosal melalui jalur yang sama seperti bakteri komensal dalam mempengaruhi respon imun alami dan adaptif. Studi in vitro dan in vivo pada mencit dan manusia telah menunjukkan bahwa probiotik dapat memodulasi sel dendritik dan aktivitas sel $T$ regulatory (Treg) daripada respon $T$ helper (Th) (3). Kemampuan beberapa bakteri probiotik dalam meningkatkan aktivitas fagositosis makrofag telah diteliti oleh beberapa peneliti di luar negeri. Namun demikian, kemampuan bakteri probiotik dalam meningkatkan aktivitas fagositosis sangat tergantung pada strain bakteri. Penelitian di Cina menunjukkan bahwa pemberian bakteri probiotik Bifidobacterium adolescentis BBNN23, B. longum BBMN68, dan Lactobacillus saliva Ren dapat meningkatkan aktivitas makrofag yang ditandai dengan peningkatan aktivitas fagositosis dan produksi nitrit oksida (NO), IL-6, dan TNF- $\alpha$ (4). Beberapa penelitian lain juga menyatakan bahwa bakteri asam laktat dapat meningkatkan aktivitas fagositosis baik in vitro maupun in vivo (5-8) serta meningkatkan produksi NO $(6,7,9,10)$.

Beberapa komponen prebiotik juga telah diteliti pengaruhnya terhadap respon imun. Penelitian pada sukarelawan manusia menunjukkan bahwa asupan inulin dan oligofruktosa dapat memberikan efek menguntungkan bagi sistem imun di gut-associated lymphoid tissue (GALT). Namun, pada tingkatan sistem imun sistemik, hanya sedikit efek yang dapat ditimbulkan dengan pemberian inulin dan oligofruktosa pada manusia dewasa yang sehat. Salah satu penelitian pada hewan coba menunjukkan bahwa sistem imun intestin dan khususnya sel imun yang berhubungan dengan Peyer's patches bersifat tanggap terhadap inulin dan oligofruktosa serta metabolitnya. Mekanisme inulin dan oligofruktosa dalam meningkatkan respon imun yaitu melalui efek tidak langsung dengan cara perubahan komposisi flora usus dan peningkatan produksi short chain fatty acid (SCFA) yang berperan dalam pengaturan imun. Beberapa data juga menunjukkan efek langsung dari inulin dan oligofruktosa melalui reseptor karbohidrat pada sel epitel usus dan sel imun (11). Konsumsi beberapa jenis prebiotik juga dilaporkan dapat meningkatkan aktivitas fagositosis dan produksi NO pada makrofag. Penelitian di India menunjukkan bahwa konsumsi laktulosa dapat meningkatkan fungsi fagosit makrofag intraperitoneal (12). Penelitian di Kota Illinois, Amerika menunjukkan bahwa konsumsi oligofruktosa sebanyak $30 \mathrm{~g} / \mathrm{L}$ dapat meningkatkan aktivitas makrofag sekal dan kolonik (13).

Penelitian pemberian kombinasi probiotik $L$. plantarum Mut7 dan prebiotik dari serat ubi jalar dalam meningkatkan respon imun belum pernah ditemukan sehingga dalam penelitian ini juga akan diuji apakah kombinasi keduanya akan menimbulkan efek sinergistik atau tidak. Tujuan penelitian ini adalah untuk mengetahui pengaruh pemberian L. plantarum Mut7, serat ubi jalar, dan kombinasi keduanya terhadap aktivitas fagositosis dan produksi NO oleh makrofag peritoneum tikus Sprague Dawley yang diinfeksi S. typhimurium. 


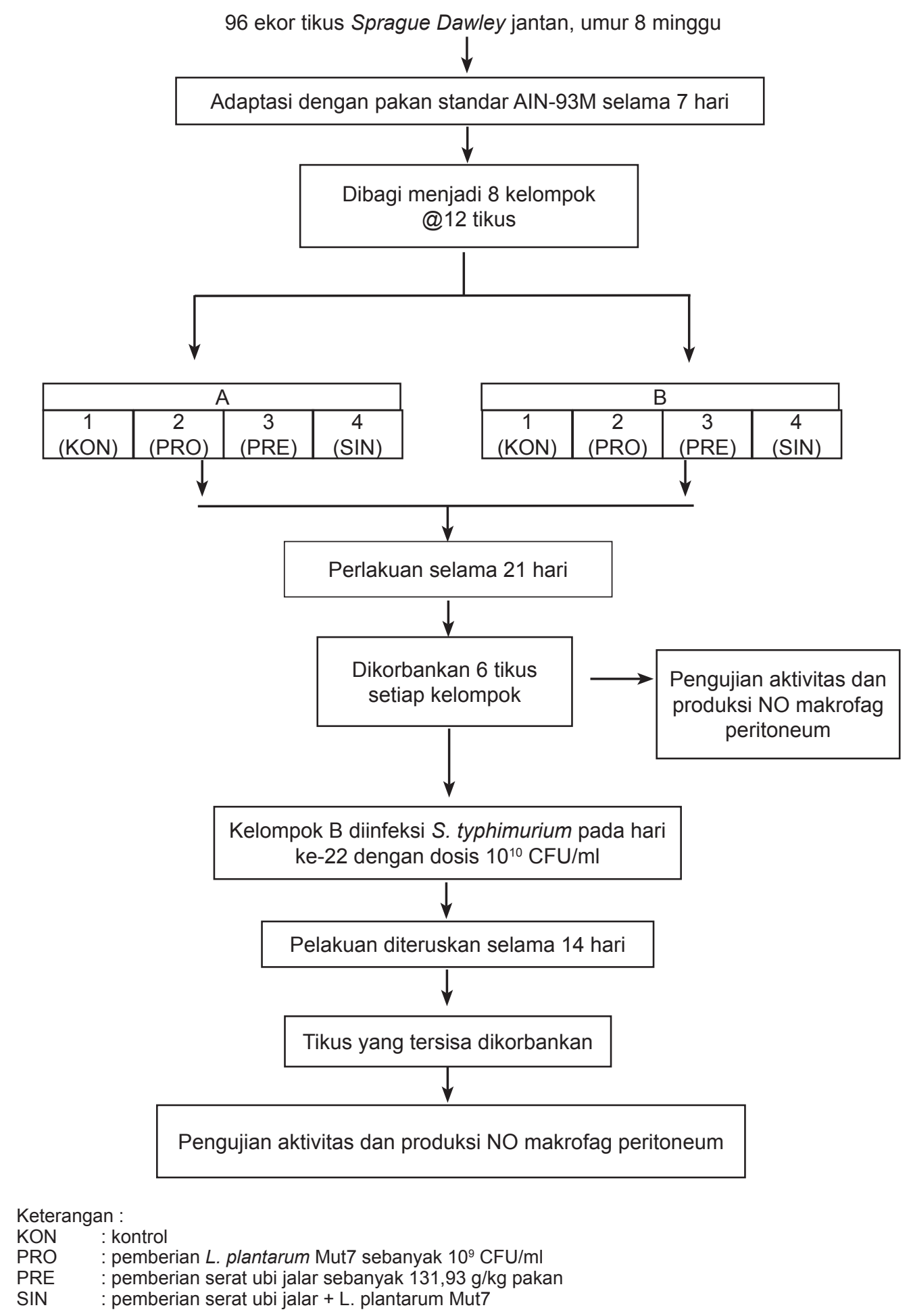

Gambar 1. Rancangan penelitian

\section{BAHAN DAN METODE}

Penelitian ini adalah penelitian eksperimental dengan rancangan randomized controlled trial (RCT) yang dilaksanakan pada bulan Mei sampai dengan Desember 2011. Subjek penelitian adalah tikus (Rattus norvegicus) strain Sprague Dawley, jantan, berumur 8 minggu, berat rata-rata 239,00 $\pm 27,66$ gram yang diperoleh dari BPOM di
Jakarta. Bakteri probiotik Lactobacillus plantarum Mut7 ( $L$. plantarum FNCC 250) dan Salmonella typhimurium FNCC 0135 diperoleh dari Food and Nutrition Culture Collection (FNCC) Pusat Studi Pangan dan Gizi Universitas Gadjah Mada, Yogyakarta. Ubi jalar varietas Bestak diperoleh dari Pasar Barakan, Karanganyar, Solo, Jawa Tengah. Ciri-ciri fisik dari ubi jalar Bestak adalah warna kulit putih kecoklatan, warna daging putih kekuningan, berbentuk 
Sel makrofag dihitung dengan hemositometer sampai mencapai $1 \times 10^{6} \mathrm{sel} / \mathrm{ml}$

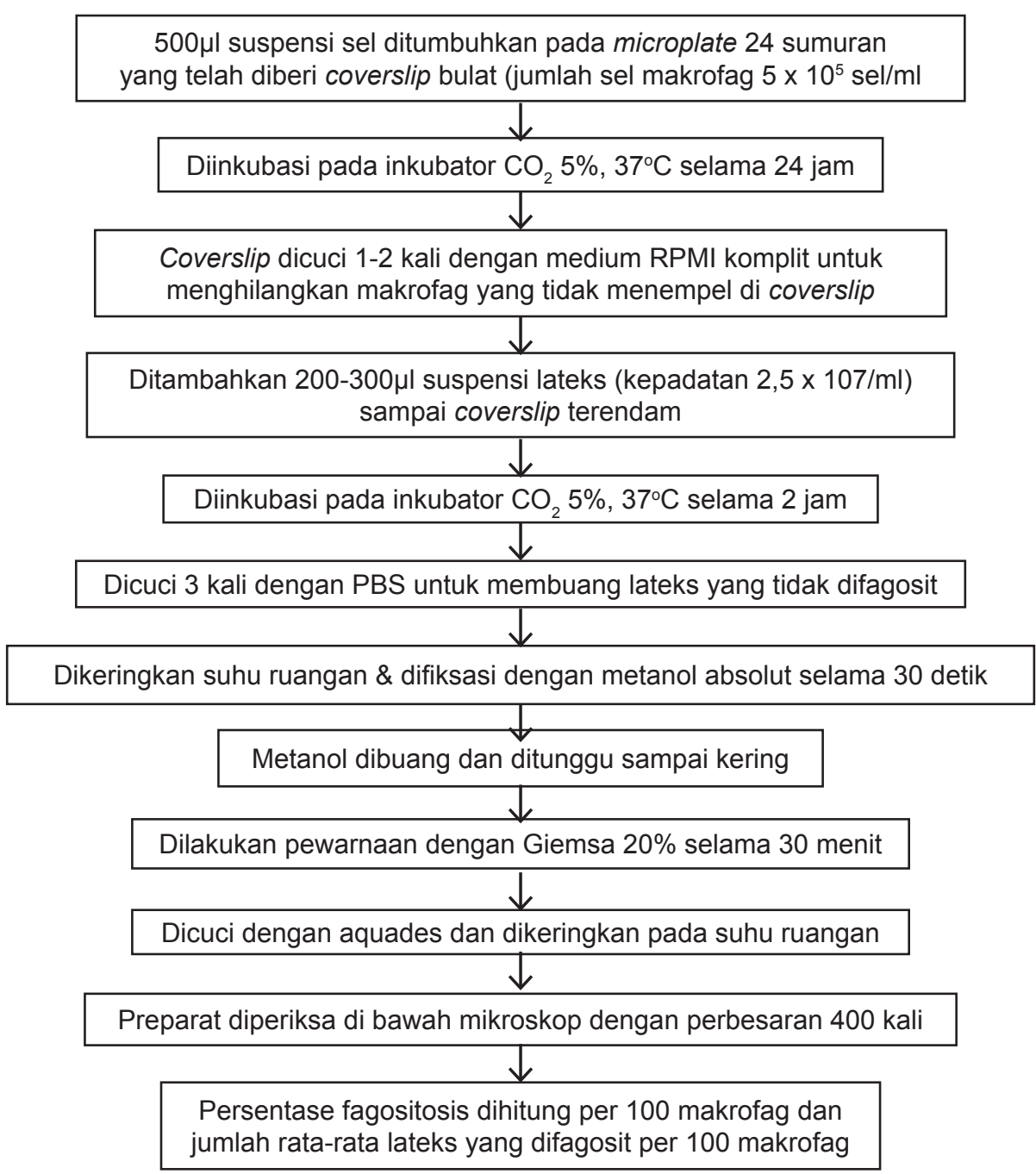

Gambar 2. Uji aktivitas fagositosis makrofag peritoneum

bulat meruncing di kedua ujungnya, diameter umbi \pm 8 $\mathrm{cm}$, dan panjang $20-25 \mathrm{~cm}$.

Variabel dalam penelitian ini adalah variabel terikat yaitu aktivitas fagositosis dan produksi NO makrofag peritoneum sedangkan variabel bebasnya yaitu pemberian $10^{9} \mathrm{CFU} / \mathrm{ml}$ sel Lactobacillus plantarum Mut7, serat ubi jalar, dan kombinasi keduanya. Pengacakan dilakukan pada waktu pemilihan hewan coba dan pembagian berdasarkan kelompok perlakuan. Sebelum masa adaptasi, tikus ditimbang berat badannya kemudian dibagi menjadi 8 kelompok perlakuan secara acak. Masa adaptasi berlangsung selama 7 hari yang bertujuan untuk penyesuaian pada lingkungan dan pakan. Tikus diberi perlakuan sesuai dengan kelompoknya selama 21 hari. Pemberian perlakuan selama 21 hari ini berdasarkan penelitian di Jerman yang menyatakan bahwa pemberian prebiotik atau sinbiotik selama 3 minggu dapat meningkatkan respon imun (14). Pada minggu ke-4, sebagian tikus (kelompok B) diinfeksi dengan Salmonella typhimurium sebesar $10^{10} \mathrm{CFU} / \mathrm{ml}$ sebanyak satu kali kemudian perlakuan probiotik, prebiotik, dan kombinasi keduanya diberikan lagi selama 14 hari (Gambar 1).

Pakan diformulasikan menurut standar American Institute of Nutrition (AIN-93M) (Tabel 1) (15). Campuran vitamin, mineral, l-sistin, dan kolin bitartrat diperoleh dari Milan Panic Biomedicals (MPBIO) Amerika. Kalsium kaseinat diperoleh dari PT Sari Husada, Yogyakarta. Pati jagung, sukrosa, agar-agar sebagai sumber serat, dan minyak kedelai diperoleh dari pasar swalayan di Yogyakarta.

Bahan kimia yang digunakan meliputi etanol teknis untuk ekstraksi serat ubi jalar. Isolasi makrofag peritoneal menggunakan media Roswell Park Memorial Institute (RPMI-1640) dari Gibco, Fetal Bovine Serum (FBS), penstrep, fungizon, dan hepes. Satu liter media RPMI dibuat dengan melarutkan 1 bungkus (10,4 gr) RPMI-1640 bubuk, ditambah hepes 2,2 gr, Na-bikarbonat 2,2 gr, dan dilarutkan dengan akuades sampai 1 liter. Medium RPMI 


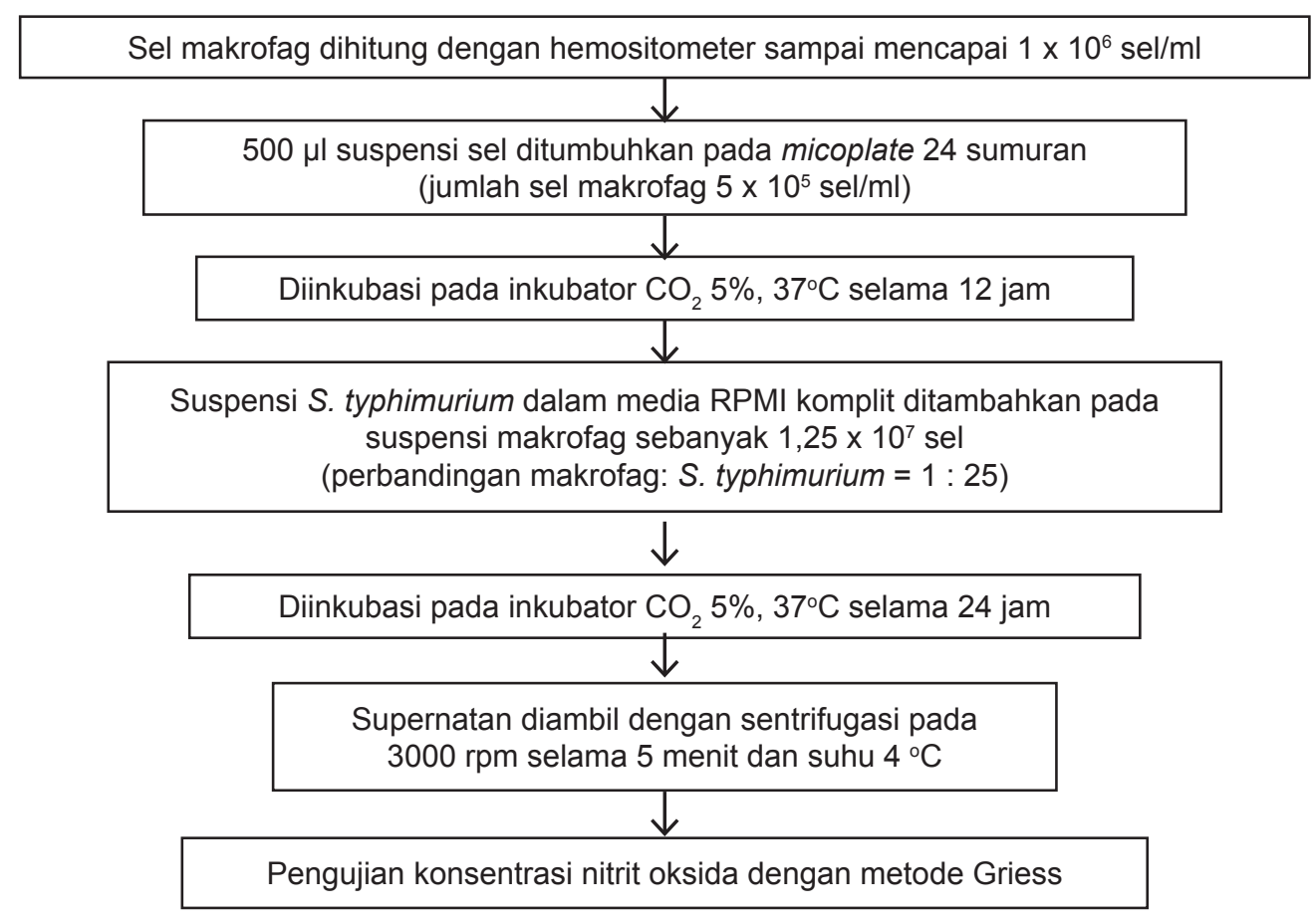

Gambar 3. Pengujian produksi nitrit oksida makrofag peritoneum

Sumber: Metode Griess mengacu pada metode yang telah dijabarkan oleh Green et al. (18)

Tabel 1. Komposisi pakan

\begin{tabular}{lcc}
\hline \multirow{2}{*}{ Bahan } & \multicolumn{2}{c}{ Diit } \\
\cline { 2 - 3 } & $\begin{array}{c}\text { Standar } \\
\text { AIN-93M (g) }\end{array}$ & $\begin{array}{c}\text { Modifikasi dengan } \\
\text { serat ubi jalar }(\mathbf{g})\end{array}$ \\
\hline Pati jagung & 620,70 & 545,87 \\
Kasein & 140,00 & 136,06 \\
Sukrosa & 100,00 & 100,00 \\
Minyak kedelai & 40,00 & 38,65 \\
Serat pangan (agar-agar) & 50,00 & 0,00 \\
Mineral & 35,00 & 33,19 \\
Vitamin & 10,00 & 10,00 \\
L-sistin & 1,80 & 1,80 \\
Kholin bitartrat & 2,50 & 2,50 \\
Serat ubi jalar & 0,00 & 131,93 \\
\hline Total & 1000,00 & 1000,0 \\
\hline Dasar perhitungan & \multicolumn{2}{c}{ ISO SERAT } \\
\hline
\end{tabular}

1640 komplit untuk inkubasi makrofag dibuat dengan komposisi yaitu $87,5 \mathrm{~mL}$ media RPMI, $2 \mathrm{ml}$ penstrep, 0,5 $\mathrm{ml}$ fungizon, dan $10 \mathrm{ml}$ FBS. Media tersebut disterilisasi dengan menggunakan filter. Peralatan yang digunakan dalam penelitian ini meliputi clean bench/laminar air flow, alat-alat gelas, autoklaf, kandang pemeliharaan tikus, inkubator suhu $37{ }^{\circ} \mathrm{C} 5 \% \mathrm{CO}_{2}$, freezer $-20{ }^{\circ} \mathrm{C}$, microplate 24 sumuran, alat bedah steril, syringe, mikropipet, tabung eppendorf, blue tip, dan yellow tip.

Besar sampel diperoleh menggunakan rumus untuk menghitung hewan coba pada penelitian yang variabelnya kontinyu misalnya konsentrasi antibodi pada serum (16) dengan simpangan baku (S) kedua kelompok sebesar 1,90 (17), perbedaan nilai (d) slgA yang diinginkan peneliti sebesar $4 \mathrm{mg} / \mathrm{mL}$, dan $\mathrm{C}$ adalah nilai konstanta yang diperoleh dari power $80 \%$, dan tingkat signifikansi $5 \%$. Besar sampel minimal untuk setiap kali sampling adalah 5 ekor tikus, tetapi untuk mengantisipasi jika ada drop out maka jumlah tikus setiap kali sampling ditambahkan $20 \%$ menjadi 6 ekor. Pada penelitian ini dilakukan 2 kali sampling masing-masing menggunakan 6 ekor tikus sehingga jumlah tikus setiap kelompok adalah 12 ekor. Perhitungan besar sampel ini mempunyai kelemahan yaitu menggunakan parameter imun yang lain (kadar slgA cairan usus) karena sulitnya mencari data penelitian dengan parameter outcome yang sama terutama penelitian yang menggunakan probiotik dan prebiotik lokal.

Isolasi makrofag peritoneal dilakukan dengan menyuntikkan $10 \mathrm{ml}$ cairan RPMI komplit dingin secara intraperitoneal pada tikus yang sebelumnya dikorbankan dengan eter atau chloroform dan ditunggu 3 - 5 menit. Kemudian cairan diaspirasi dengan menggunakan spuit injeksi, diupayakan tikus dalam posisi miring sehingga pengambilan cairan lebih mudah dilakukan. Pengujian aktivitas fagositosis makrofag peritoneum dapat dilihat pada Gambar 2 sedangkan pengujian produksi NO pada makrofag peritoneum dapat dilihat pada Gambar 3.

Data yang diperoleh diuji menggunakan analisis varian (one way ANOVA pada uji parametrik atau KruskallWallis pada uji non parametrik) yang bertujuan untuk mengetahui ada tidaknya perbedaan antar kelompok dilanjutkan dengan Post Hoc (Tukey atau Mann-Whitney test) untuk mengetahui pada kelompok mana perbedaan tersebut bermakna. 
Tabel 2. Persentase makrofag yang memfagosit partikel lateks dan jumlah partikel lateks yang difagosit tiap makrofag

\begin{tabular}{lccccc}
\hline \multirow{2}{*}{ Kelompok } & \multirow{2}{*}{ Perlakuan } & \multicolumn{2}{c}{$\%$ M $\phi$ yg memfagosit } & \multicolumn{2}{c}{$\sum$ lateks yang difagosit tiap M $\phi$} \\
\cline { 2 - 5 } Tidak Diinfeksi & Minggu ke-3 & Minggu ke-5 & Minggu ke-3 & Minggu ke-5 \\
\cline { 2 - 5 } & KON & $26,25 \pm 9,76^{\mathrm{a}}$ & $38,86 \pm 16,65^{\mathrm{a}}$ & $1,53 \pm 0,20^{\mathrm{a}}$ & $2,01 \pm 0,33^{\mathrm{a}}$ \\
& PRO & $70,90 \pm 6,47^{\mathrm{b}}$ & $74,72 \pm 7,41^{\mathrm{b}}$ & $2,60 \pm 0,84^{\mathrm{b}}$ & $5,13 \pm 0,73^{\mathrm{b}}$ \\
& PRE & $76,51 \pm 4,69^{\mathrm{b}}$ & $70,44 \pm 9,78^{\mathrm{b}}$ & $3,33 \pm 0,13^{\mathrm{b}}$ & $4,02 \pm 0,73^{\mathrm{b}}$ \\
\multirow{5}{*}{ Diinfeksi } & SIN & $79,93 \pm 6,87^{\mathrm{b}}$ & $86,74 \pm 7,07^{\mathrm{c}}$ & $4,58 \pm 0,52^{\mathrm{c}}$ & $4,79 \pm 0,64^{\mathrm{b}}$ \\
& KON & $50,42 \pm 1,09^{\mathrm{c}}$ & $51,99 \pm 4,72^{\mathrm{a}}$ & $1,96 \pm 0,10^{\mathrm{d}}$ & $2,36 \pm 0,55^{\mathrm{a}}$ \\
& PRO & $76,12 \pm 2,83^{\mathrm{d}}$ & $85,61 \pm 6,95^{\mathrm{d}}$ & $2,69 \pm 0,13^{\mathrm{e}}$ & $5,29 \pm 0,51^{\mathrm{c}}$ \\
& PRE & $68,01 \pm 5,87^{\mathrm{e}}$ & $82,33 \pm 5,10^{\mathrm{d}}$ & $3,00 \pm 0,39^{\mathrm{e}}$ & $4,49 \pm 0,44^{\mathrm{c}}$ \\
& SIN & $87,52 \pm 9,58^{\mathrm{d}}$ & $86,61 \pm 5,92^{\mathrm{d}}$ & $4,19 \pm 0,62^{\mathrm{f}}$ & $4,38 \pm 0,51^{\mathrm{d}}$ \\
\hline
\end{tabular}

Keterangan:

$a, b, c, d, e$ : superskrip yang sama pada kolom yang sama menyatakan tidak beda nyata $(p>0,05)$

$\Sigma \quad$ : jumlah

$\mathrm{M} \varphi \quad$ : makrofag

KON : kontrol

PRO : pemberian L. plantarum Mut7 sebanyak $10^{9} \mathrm{CFU} / \mathrm{ml}$

PRE : pemberian serat ubi jalar sebanyak $131,93 \mathrm{~g} / \mathrm{kg}$ pakan

SIN : pemberian serat ubi jalar + L. plantarum Mut7

Tabel 3. Produksi nitrit oksida makrofag peritoneum

\begin{tabular}{lccc}
\hline \multirow{2}{*}{ Kelompok } & \multirow{2}{*}{ Perlakuan } & \multicolumn{2}{c}{ Produksi nitrit oksida $(\mu \mathrm{M})$} \\
\cline { 3 - 4 } & & Minggu ke-3 & Minggu ke-5 \\
\hline Tidak Diinfeksi & KON & $0,386 \pm 0,227^{\mathrm{a}, \mathrm{x}}$ & $5,509 \pm 0,418^{\mathrm{a}, \mathrm{y}}$ \\
& PRO & $0,543 \pm 0,383^{\mathrm{a}, \mathrm{x}}$ & $4,585 \pm 1,453^{\mathrm{a}, \mathrm{y}}$ \\
& PRE & $0,450 \pm 0,169^{\mathrm{a}, \mathrm{x}}$ & $5,889 \pm 0,924^{\mathrm{a}, \mathrm{y}}$ \\
\multirow{5}{*}{ Diinfeksi } & SIN & $0,260 \pm 0,069^{\mathrm{a}, \mathrm{x}}$ & $2,749 \pm 0,709^{\mathrm{b}, \mathrm{y}}$ \\
& KON & $0,635 \pm 0,268^{\mathrm{a}, \mathrm{x}}$ & $1,390 \pm 0,275^{\mathrm{b}, \mathrm{y}}$ \\
& PRO & $1,073 \pm 0,202^{\mathrm{b}, \mathrm{x}}$ & $1,453 \pm 0,259^{\mathrm{b}, \mathrm{y}}$ \\
& PRE & $0,390 \pm 0,040^{\mathrm{a}, \mathrm{x}}$ & $4,895 \pm 2,556^{\mathrm{a}, \mathrm{y}}$ \\
& SIN & $0,404 \pm 0,116^{\mathrm{a}, \mathrm{x}}$ & $6,067 \pm 2,257^{\mathrm{a}, \mathrm{y}}$ \\
\hline
\end{tabular}

Keterangan :

a, b, c, d, e, f : superskrip yang sama pada kolom yang sama menyatakan ada beda nyata $(p<0,05)$

$\quad:$ : superskrip yang sama pada baris yang sama menyatakan tidak ada beda nyata $(p>0,05)$

KON : kontrol

PRO : pemberian L. plantarum Mut7 sebanyak $10^{9} \mathrm{CFU} / \mathrm{ml}$

PRE : pemberian serat ubi jalar sebanyak $131,93 \mathrm{~g} / \mathrm{kg}$ pakan

SIN : pemberian serat ubi jalar + L. plantarum Mut7

\section{HASIL}

\section{Aktivitas fagositosis makrofag peritoneum}

Aktivitas fagositosis diukur berdasarkan kemampuan makrofag memfagosit partikel lateks. Perbandingan jumlah makrofag dan partikel lateks yaitu $1: 10$. Pemberian $L$. plantarum Mut7, serat ubi jalar, dan gabungan keduanya dapat meningkatkan aktivitas fagositosis makrofag. Data yang lebih konsisten kecenderungannya dapat dilihat dari rerata jumlah lateks yang difagosit tiap makrofag (Tabel 2). Efek yang paling tinggi yaitu pada tikus yang diberi $L$. plantarum Mut7 dan serat ubi jalar diikuti serat ubi jalar saja dan L. plantarum Mut7 saja. Jumlah partikel lateks yang difagosit oleh makrofag peritoneum meningkat dengan pemberian L. plantarum Mut7, serat ubi jalar, dan gabungan keduanya (Gambar 4).

\section{Produksi nitrit oksida (NO) oleh makrofag peritoneum}

Jika dibandingkan dengan kontrol, maka produksi NO setelah minggu ke-3 perlakuan L. plantarum Mut7 lebih tinggi. Sementara itu, perlakuan serat ubi jalar dan gabungan keduanya tidak dapat meningkatkan produksi NO. Setelah perlakuan diperpanjang sampai minggu ke-5, produksi NO meningkat pada semua kelompok jika dibandingkan minggu ke-3 $(p<0,05)$.

Pada kelompok yang tidak diinfeksi $S$. typhimurium, tidak ada perbedaan produksi NO pada tikus yang diberi $L$. plantarum Mut7 dan serat ubi jalar jika dibandingkan dengan kontrol. Sementara itu, pada kelompok perlakuan gabungan keduanya, produksi NO lebih kecil dibandingkan kontrol. Pada kelompok yang diinfeksi S. typhimurium, produksi NO 
KON - Pakan Standar AIN-93M

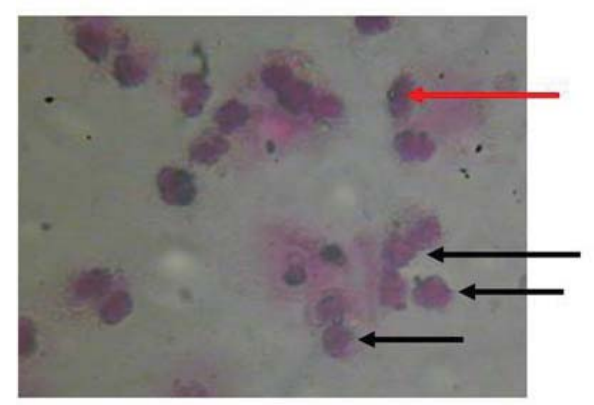

PRE - Ekstrak Serat Ubi Jalar

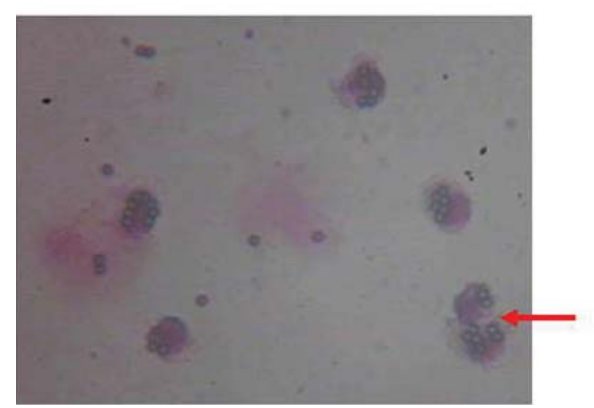

PRO - L. plantarum Mut7

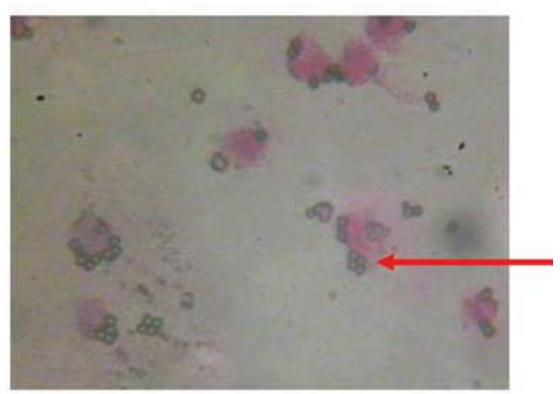

SIN - L. plantarum Mut7 + Ekstrak Serat Ubi Jalar

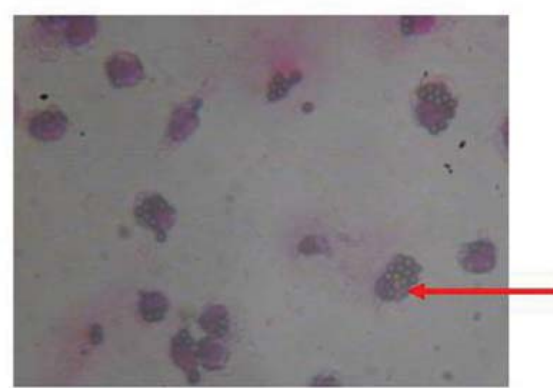

Gambar 4. Makrofag yang memfagosit partikel lateks

Keterangan:

(anak panah merah) : makrofag yang memfagosit

(anak panah hitam) : makrofag yang tidak memfagosit

pada tikus yang diberi perlakuan kontrol dan L. plantarum Mut7 hampir sama, sementara yang diberi serat ubi jalar dan gabungan serat ubi jalar dan L. plantarum Mut7 lebih tinggi dibandingkan kontrol (Tabel 3).

\section{BAHASAN}

Makrofag berperan penting pada respon imun alami di saluran cerna dan mewakili salah satu pertahanan terdepan non spesifik melawan invasi bakteri. Bakteri probiotik dapat meningkatkan aktivitas fagositosis makrofag karena makrofag mempunyai reseptor spesifik Gal/GalNAc yang dapat mengenali residu galaktosa pada permukaan bakteri (19). Makrofag juga mempunyai reseptor berupa Toll-like Receptor (TLR) yang dapat mengenali komponen dinding sel bakteri misalnya TLR4 yang mengenali lipopolisakarida (LPS), kemudian TLR1, TLR2, TLR6 yang mengenali peptidoglikan, TLR2 yang mengenali asam lipoteikoat, dan nucleotide-binding oligomerization domain (NOD1 / NOD2) yang mengenali hasil hidrolisis peptidoglikan $(20,21)$.

Aktivasi makrofag dapat diukur dengan berbagai parameter yaitu kemampuan fagositosis, aktivitas bakterisidal, dan karakteristik biokimiawi. Pada penelitian ini dilakukan 2 macam pengukuran yaitu kemampuan makrofag dalam memfagosit partikel lateks dan memproduksi NO. Bakteri probiotik yang diberikan yaitu $L$. plantarum
Mut7 sebanyak $10^{9} \mathrm{CFU} / \mathrm{ml}$ dan sel berada dalam fase logaritmik akhir. Penelitian di Belanda menunjukkan bahwa fase pertumbuhan dan viabilitas sel probiotik dapat mempengaruhi respon imun yang ditimbulkan. $L$. plantarum WCFS1 pada fase logaritmik, stasioner, atau sel mati diberikan kepada sukarelawan sehat. Setelah 6 jam pemberian sel probiotik, sampel diambil dari duodenum dan dianalisis ekspresi gennya. Hasil penelitian menunjukkan bahwa pola ekspresi gen pada permukaan mukosa berhubungan dengan toleransi sistem imun. Sel probiotik dalam 3 fase tersebut (logaritmik, stasioner, mati) terbukti dapat menginduksi gen yang berhubungan dengan respon imun. Namun demikian, tipe induksi dan jumlah gen yang menginduksi berbeda antara fase logaritmik dan stasioner. Sel pada fase logaritmik menginduksi respon terhadap fungsi metabolisme seperti metabolisme asam nukleat dan organisasi pada sitoplasmik. Sementara itu, sel bakteri pada fase stasioner menginduksi gen seperti nuclear factor kappa beta (NF-K $\beta$ ) dan faktor transkripsi Jun yang dapat mempengaruhi toleransi sistem imun. Sel bakteri probiotik yang dimatikan (dengan cara pemanasan) ternyata memberikan efek yang sebanding dengan sel probiotik hidup pada fase stasioner (22).

L. plantarum Mut7 merupakan bakteri gram positif sehingga dinding selnya mengandung peptidoglikan dan asam teikoat. Pengenalan bakteri probiotik oleh sel-sel imun ini dipengaruhi oleh komposisi dinding sel sehingga 
meskipun sama-sama termasuk dalam kelompok bakteri asam laktat (BAL), antar spesies mempunyai pattern recognitions receptors (PRR) yang berbeda. TLR2 dapat mengenali peptidoglikan dan asam lipoteikoat, TLR9 dapat mengenali $\mathrm{CpG}$ deoxyribose-nucleic acid (CpG DNA), dan NOD2 dapat mengenali muramyl dipeptida (MDP) (23). Adanya reseptor spesifik pada makrofag yang dapat mengenali bakteri probiotik ini dapat menyebabkan adanya mekanisme toleransi imun.

Hasil penelitian ini juga menunjukkan bahwa pemberian serat ubi jalar dapat meningkatkan aktivitas fagositosis makrofag. Hal ini sejalan dengan penelitian di India yang menunjukkan bahwa konsumsi laktulosa dapat meningkatkan fungsi fagosit makrofag intraperitoneal (12). Sementara itu, penelitian di Amerika menunjukkan bahwa konsumsi oligofruktosa sebanyak $30 \mathrm{~g} / \mathrm{L}$ dapat meningkatkan aktivitas makrofag sekal dan kolonik (13). Prebiotik biasanya berupa oligosakarida dan bersifat tahan cerna. Oligosakarida tersusun atas beberapa unit monosakarida seperti fruktosa, glukosa, dan galaktosa. Makrofag dapat mengenali struktur berulang monosakarida pada polisakarida dan oligosakarida sehingga dapat memacu respon imun dengan peningkatan aktivitas fagositosis makrofag. Beberapa reseptor spesifik pada makrofag yaitu manosa dan lipopolisakarida (20).

Nitrit oksida merupakan radikal bebas yang berupa gas anorganik dan bersifat dapat menembus lapisan membran. NO berperan penting pada berbagai fungsi fisiologis salah satunya adalah sebagai mediator kunci pada imunitas non spesifik. NO dapat diproduksi selama aktivasi makrofag oleh antigen seperti bakteri, virus, dan parasit. NO bersifat toksik terhadap bakteri patogen karena NO dapat menghambat enzim ribonukleotida reduktase dan mengganggu sintesis DNA. NO juga dapat menginaktivasi enzim yang berikatan dengan zat besi dan sulfur seperti Nicotinamide Adenine Dinucleotide (NADH) dan ubikuinon oksidoreduktase. Meskipun NO sendiri bersifat cukup toksik dan secara alami sifatnya reaktif, maka NO dapat dengan mudah berikatan dengan molekul lain seperti oksigen dan menghasilkan nitrat dan nitrit yang bersifat stabil dan tidak toksik (24).

Hasil penelitian ini menunjukkan bahwa secara umum produksi NO antar perlakuan tidak berbeda signifikan. Pengaruh probiotik dan prebiotik terhadap produksi NO pada makrofag memang masih kontroversi. Beberapa penelitian menyatakan bahwa probiotik dapat meningkatkan produksi NO $(5,7)$. Sementara itu, hasil penelitian di Korea menunjukkan bahwa asam lipoteikoat (LTA) yang terdapat pada bakteri gram postif tidak dapat menginduksi produksi NO pada cell line makrofag RAW 264.7 kecuali jika terdapat interferon gamma (IFN-y). Penelitian ini menggunakan LTA murni yang diisolasi dari bakteri L. plantarum. Produksi NO dihambat oleh inhibitor NO sintase (NOS) yaitu 1-NAME dan inhibitor inducible
NOS (iNOS) yaitu 1-NIL. Kesimpulan dari penelitian di Korea ini adalah keberadaan IFN- $y$ dapat meningkatkan aktivitas pengikatan DNA dari faktor transkripsi NF-KB yang telah diketahui terlibat pada ekspresi gen iNOS (10).

Sementara itu, penelitian yang dilakukan di Indiana, Amerika Serikat mengenai efek pemberian serat arabinoksilan dari sekam jagung dan kulit pisang terhadap aktivitas makrofag dan pertumbuhan ayam menunjukkan bahwa arabinoksilan dari kedua bahan makanan tersebut dapat mengaktifkan makrofag, menghambat penempelan Salmonella pada usus, dan meningkatkan berat badan ayam selama penelitian. Berdasarkan penelitian ini dapat disimpulkan bahwa serat pangan yang berupa arabinoksilan dapat digunakan sebagai agensia yang dapat meningkatkan kesehatan melalui peningkatan respon imun hewan coba (25). Ekstrak serat ubi jalar pada penelitian ini juga dapat meningkatkan aktivitas fagositosis makrofag yang ditandai dengan peningkatan jumlah makrofag yang memfagosit partikel lateks, jumlah lateks yang difagosit, dan produksi NO.

Aktivasi makrofag baik oleh bakteri probiotik maupun prebiotik mempunyai peranan penting dalam respon imun alami dan adaptif. Aktivasi makrofag dapat memacu sekresi beberapa jenis sitokin yang selanjutnya sitokin akan berperan dalam memodulasi sistem imun adaptif. Modulasi sistem imun alami ini dapat mempengaruhi kemampuan inang untuk merespon secara cepat jika terkena infeksi berbagai macam patogen (26).

\section{SIMPULAN DAN SARAN}

Pemberian L. plantarum Mut7, serat ubi jalar, dan gabungan keduanya dapat meningkatkan aktivitas fagositosis makrofag yang ditandai dengan peningkatan persentase makrofag yang memfagosit partikel lateks dan rerata jumlah partikel lateks yang difagosit tiap makrofag baik setelah 3 dan 5 minggu perlakuan. Pemberian $L$. plantarum Mut7, serat ubi jalar, dan gabungan keduanya tidak dapat meningkatkan produksi NO setelah minggu ke-3 perlakuan, tetapi perlakuan selama 5 minggu dapat meningkatkan produksi NO. Penelitian lebih lanjut perlu dilakukan untuk melihat pengaruh pemberian probiotik dan prebiotik lokal terhadap parameter imun yang lain seperti slgA pada cairan usus, produksi IgM, IgG, dan IgA serum, populasi sel T dan sel B, proliferasi limfosit, atau produksi sitokin pada Peyer's Patch.

\section{UCAPAN TERIMA KASIH}

Penelitian ini didanai oleh Yayasan Institut Danone Indonesia melalui Doctorate Grant No. D-0132010 tahun 2011. Pandangan yang dikemukakan di dalam naskah publikasi ini adalah pendapat dari masing-masing penulis dan tidak mencerminkan pandangan dari Yayasan Institut Danone Indonesia. 


\section{RUJUKAN}

1. Anonim. Peraturan kepala badan pengawasan obat dan makanan No. 00.05.52.0685 tentang ketentuan pokok pengawasan pangan fungsional. [serial online] 2005 [cited 2012 Jan 5]. Available from: URL: http.// www.pom.go.id/public/hukum_perundangan/pdf/ SK\%20PanFUNGSI\%20.pdf

2. Lestari LA, Soesatyo MHNE, Iravati S, Harmayani E. Karakteristik ubi jalar (Ipomoea batatas) varietas bestak sebagai sumber prebiotik lokal. Simposium Gizi Nasional; 2011 Okt 15; Yogyakarta.

3. Lee YK, Salminen S. Handbook of probiotics and prebiotics. New Jersey: John Wiley \& Sons; 2009.

4. Zhu J, Zhao L, Guo H, Jiang L, Ren F. Immunomodulatory effects of novel Bifidobacterium and Lactobacillus strains on murine macrophage cells. Af $\mathrm{J}$ Microbiol Res 2011;5(1):8-15.

5. Hatcher GE, Lambrecht RS. Augmentation of macrophage phagocytic activity by cell-free extracts of selected lactic acid-producing bacteria. J Dairy Sci 1993;76(9):2485-92.

6. Tejada-Simon MV, Pestka JJ. Proinflammatory cytokine and nitric oxide induction in murine macrophage by cell wall and cytoplasmic extracts of lactic acid bacteria. J Food Prot 1999;62(12):1435-44.

7. Kim DW, Cho SB, Yun CH, Jeong HY, Chung WT, Choi CW, Lee HJ, Nam IS, Suh GH, Lee SS, Lee BS. Induction of cytokines and nitric oxide in murine macrophages stimulated with enzymatically digested Lactobacillus strains. J Microbiol 2007;45(5):373-8.

8. Lin $\mathrm{WH}, \mathrm{Wu} C \mathrm{CR}$, Fang $\mathrm{TJ}$, Lee $\mathrm{MS}$, Lin $\mathrm{KL}$, Chen HC, Huang SY, Hseu YC. Adherent properties and macrophage activation ability of 3 strains of lactic acid bacteria. J Food Sci 2007;76(1):M1-7.

9. Kawashima T, Hayashi K, Kosaka A, Kawashima M, Igarashi T, Tsutsui H, Tsuji NM, Nishimura I, Hayashi $\mathrm{T}$, Obata A. Lactobacillus plantarum strain YU from fermented foods activates Th1 and protective immune responses. Int Immunopharmacol 2011;11(12):201724.

10. Kang SS, Ryu YH, Baik JE, Yun CH, Lee K, Chung DK, Han SH. Lipoteichoic acid from Lactobacillus plantarum induces nitric oxide production in the presence of interferon- $y$ in murine macrophages. Mol Immunol 2011;48(15-16):2170-7.

11. Seifert S, Watzl B. Inulin and oligofructose: review of experimental data on immune modulation. J Nutr 2007;137(11):2563S-7S.

12. Nagendra R, Venkat Rao $S$. Effect of feeding infant dietary fibres, prebiotics and immune functions formulations containing bifidus factors on in vivo proliferation of bifidobacteria and stimulation of intraperitoneal macrophage activity in rats. J Nutr Imm 1994;2:61-68.

13. Gaskins HR, Mackie RI, May T, Garleb KA. Dietary fructo-oligosaccharide modulates large intestinal inflammatory responses to Clostridium difficile in antibiotic-compromised mice. Microb Ecol Health Dis 1996;9(4):157-66.

14. Seifert S, Watzl B. Prebiotics and the immune system: review of experimental and human data. In: Handbook of prebiotics. Gibson GR, Roberfroid MB, editors. Boca Raton: CRC Press; 2009.

15. Reeves PG, Nielssen FH, Fahey GC. AIN-93 purified diets for laboratory rodents: final report of the American Institute of Nutrition ad hoc writing committee on the reformulation of the AIN-76A rodent diet. J Nut 1993;123(11):1939-51.

16. Dell RB, Holleran S, Ramakrishnan R. Sample size determination. ILAR J 2002;43(4):207-13.

17. Kusumawati ID, Harmayani E, Asmara W. Pengaruh probiotik Lactobacillus spp. Dad13 terhadap sistem imun humoral mencit Balb/c yang diinfeksi Salmonella typhimurium [Tesis]. Yogyakarta: Program Studi Bioteknologi UGM; 2006.

18. Green LC, Wagner DA, Glogowski J, Skipper PL, Wishnok JS, Tannenbaum SR. Analysis of nitrate, nitrite, and [15N] nitrate in biological fluids. Anal Biochem 1982;126(1):131-8.

19. Ouwehand AC, Kirjavainen PV, Shortt C, Salminen S. Probiotics: mechanisms and established effects. Internat Dairy J 1999;9(1):43-52.

20. Baratawdjaya KG, Rengganis I. Imunologi dasar. Edisi ke-8. Jakarta: FK UI; 2009.

21. MacDonald TT, Gordon JN. Bacterial regulation of intestinal immune responses. Gastroenterol Clin North Am 2005;34(3):401-12.

22. O'Flaherty S, Saulnier DM, Pot B, Versalovic J. How can probiotics and prebiotics impact mucosal immunity?. Gut Microbes 2010;1(5):293-300.

23. Borchers AT, Selmi C, Meyers FJ, Keen CL, Gershwin E. Probiotic and immunity. J Gastroenterol 2009;44(1):2646.

24. Billack B. Macrophage activation: role of toll-like receptors, nitric oxide, and nuclear factor kappa B. Am J Pharmaceutical Edu 2006;70(5):1-10.

25. Zhang $P$, Wampler JL, Bhunia AK, Burkholder $\mathrm{KM}$, Patterson JA, Whistler RL. Effect of arabinoxylans on activation of murine macrophages and growth performance of broiler chicks. AACC 2004;81(4):511-4.

26. Beutler B. Innate immunity: an overview. Mol Immunol 2004;40(12):845-59. 